\title{
PHYSICAL, MECHANICAL AND THERMAL BEHAVIOR OF ADOBE STABILIZED WITH "SYNTHETIC TERMITE SALIVA"
}

\author{
Rômulo M. Gandia ${ }^{1 *}$, Andrea A. R. Corrêa ${ }^{2}$, Francisco C. Gomes², Diego B. Marin², Lucas S. Santana² \\ ${ }^{1 *}$ Corresponding author. Federal University of Lavras/ Lavras - MG, Brazil. \\ E-mail: romagandia@gmail.com | ORCID ID: https://orcid.org/0000-0002-7786-1525
}

\section{KEYWORDS}

Nonconventional materials, stabilization, sustainability, earth construction, hydrophobicity.

\begin{abstract}
Adobe is an efficient construction material for several reasons, such as its thermal comfort, sustainability, and lower energy cost, as well as the simplicity of its production and execution. However, challenges such as water absorption, capillarity, and compressive strength should be investigated to improve its physical and mechanical properties. "Synthetic termite saliva" (STS) is an excellent stabilizer with high cohesive and hydrophobic power. Therefore, the objective of this work was to evaluate the effects of STS incorporation into adobe, analyzing its physical, mechanical and thermal properties. Five treatments were studied: 0 (control); $0.1 ; 0.2 ; 0.4$ and $0.8 \%$ STS by mass. These adobe samples were evaluated according to bulk density, linear shrinkage, capillarity, water absorption, thermal conductivity and compressive strength, according to Norma Técnica de Edificación (NTE) E0.80 testing using a new methodology. Linear shrinkage decreases from 2.7 to $1.91 \mathrm{~cm}$ with $0.4 \%$ STS. Capillarity decreases with the increasing amounts of STS. Water absorption decreased from 12.03 to $6.31 \%$ using $0.4 \%$ STS, and its mass was reduced from 779 to 19 grams. The thermal conductivity showed no differences between concentrations. The compressive strength was reduced but was still acceptable based on NTE E.080. The stabilization of the adobe using STS showed an improvement in its physical properties, mainly due to its hydrophobic power.
\end{abstract}

\section{INTRODUCTION}

There are numerous materials and products developed for the construction industry. All of these products have an aggregate energy value in production because they use natural resources, raw materials, machinery and human labor. Adobe is a material produced using soil and water; when necessary, fibers or other stabilizers are added (Galán-Marín et al., 2010).

Due to its raw material being soil and due to the nonoccurrence of sintering in its production, adobe is considered a sustainable construction material (Corrêa et al., 2015) that has low energy costs (Shukla et al., 2009; Gandia et al., 2018). Adobe presents a low thermal conductivity compared to traditional building materials, exhibits an excellent thermal comfort by the nonvitrification process, displays greater porosity and has the ability to store energy for a longer period of time (Balkis, 2017).

The amount of water used in adobe production is 60 times lower than that in cement production (Corrêa et al., 2015). Because adobe is a material that is most often handcrafted, its mechanical properties are quite variable (Illampas et al., 2014).

Adobes are considered green building materials because they have low levels of carbon incorporated compared to conventional materials such as concrete and ceramic bricks. For these reasons, in recent decades, new research has focused on earth construction as a building material worldwide (Millogo et al., 2016).

Despite the advantages, adobe destabilizes when exposed to water, making its use a challenge. The use of natural and synthetic fibers, waste and other stabilizers to improve the properties of adobe has become a target of study. Much research has been done to improve the physical properties of water absorption and capillarity in adobe using several stabilizers: Vilane (2010), Piattoni et al. (2011), Millogo et al. (2014), Corrêa et al. (2015), Aguilar el al. (2016), Dove et al. (2016), Hamard et al. (2016), Laborel-Préneron et al. (2016), Millogo et al. (2016), Stazi et al. (2016), Eires et al. (2017) and Nakamatsu et al. (2017).

The stabilizer called "synthetic termite saliva" (STS) has recently been used in asphaltic subgrade to

\footnotetext{
${ }^{2}$ Federal University of Lavras/ Lavras - MG, Brazil.

Received in: 5-3-2018

Accepted in: 12-19-2018
} 
replace cement and gravel. The STS, when incorporated into the soil, presents greater clay mineral particle cohesion and high hydrophobicity. There has been some research using STS in adobe. Corrêa et al. (2014a, 2014b, 2015), found excellent results in the physical-mechanical properties of adobe, mainly due to the stabilization when the adobe came in contact with water. In soil-cement, Faria et al. (2016) found satisfactory results using STS.

Therefore, the use of "synthetic termite saliva" is studied because it is a nontoxic chemical derived from natural oils (babassu, castor bean and others) that has hydrophobic and cohesive properties in soils. The product resembles termite saliva, which can waterproof and join the soil components in their habitat. Used in vicinal and asphalt pavements, it replaces the use of stabilizers such as lime, gravel and cement, reducing costs and avoiding environmental damage.

This work was carried out to contribute to the search for innovation, by proposing a composite that meets standardized technical specifications and is focused on sustainability. Therefore, the objective is to analyze the incorporation of "synthetic termite saliva" into adobe with the aim of improving its physical and mechanical properties.

\section{MATERIAL AND METHODS}

The treatments were named C (control), STS1, STS2, STS4 and STS8 representing $0 ; 0.1 ; 0.2 ; 0.4$ and $0.8 \%$ STS by mass in the adobe, respectively. All of the samples were made in the same period, dried for 35 days, protected from the sun and weather and used the same dimensions of shapes $(30 \times 15 \times 8 \mathrm{~cm})$.

The STS was provided by BLINDA SOLO, located in Ouro Fino / MG. The choice of product took into account nontoxicity, cohesive power and water repellency. The choice in concentrations was according to the manufacturer's recommendations and based on Corrêa et al. (2015), which analyzed the behavior of a more concentrated solution. It is noteworthy that references to the use of STS in adobe are scarce.
The samples of adobe were submitted to 7 variables and then divided for physical, mechanical and thermal tests. The physical tests were for bulk density, linear shrinkage, water absorption and capillarity. The mechanical tests were for compressive strength, following the NTE E.080 (NTE, 2000), and to test another methodology for cutting the adobes after demolding. The thermal test was for the thermal conductivity using the methodology of Silva (2010). For each physical and thermal assay, a simple completely randomized design was used. For the mechanical tests, the completely randomized design was used in a 5:2 factorial scheme, with 5 being the STS addition factor and 2 being the two methodologies of the NTE E. 080 cut before and after the adobes dried.

\section{Material characterization}

The soil belongs to the B horizon with a depth of $1.3 \mathrm{~m}$, was free of organic matter, and was located on the campus of the Federal University of Lavras. It is classified as red latosol (EMBRAPA, 2013) with a very clayey texture. A correction of the soil was made in the proportion of $600 \mathrm{~kg}$ of sand for each $1000 \mathrm{~kg}$ of soil. The sand used is commercially called medium sand. Table 1 shows the characteristics of the soil in natura and the soil corrected. Figure 1 shows the granulometric size curve of the soil in natura, corrected soil and sand used for correction. The X-ray diffraction of the soil, represented by Figure 2, identified the presence of kaolinite.

After correction with the sand, the soil fits the ideal texture for the production of adobes, with at least $40 \%$ of sand in its composition. Fratini et al. (2011) states that clay and silt should not exceed $55 \%$ because levels above that amount reduces the mechanical strength due to retraction in drying and possible fissures.

The liquid limit and plastic limit are decreased after soil correction, so the amount of water required for adobe production will be lower. The ideal value of water for adobe production, according to Corrêa et al. (2015), is within the liquid and plastic limit.

TABLE 1. Properties of soil and soil corrected with sand.

\begin{tabular}{|c|c|c|c|c|c|}
\hline & & Soil in natura & Soil corrected (soil+sand) & Unit & Method \\
\hline \multirow{3}{*}{ Granulometry } & Clay & 66 & 41 & $\%$ & \\
\hline & Silt & 6 & 2 & $\%$ & NBR 7181/84 \\
\hline & Sand & 28 & 57 & $\%$ & \\
\hline \multirow{3}{*}{ Consistency limits } & LL & 40.02 & 27.02 & $\%$ & NBR 6459/04 \\
\hline & LP & 29.79 & 20.30 & $\%$ & NBR 7180/81 \\
\hline & $\mathrm{LC}$ & 16.80 & 19.02 & $\%$ & NBR 7183, adapted \\
\hline Density & Specific mass & 1.98 & 2.37 & $\mathrm{~g} \mathrm{~cm}^{-3}$ & NBR 9776/DNER-ME 093/94 \\
\hline
\end{tabular}

LL: liquid limit, LP: plastic limit, LC: contraction limit. 


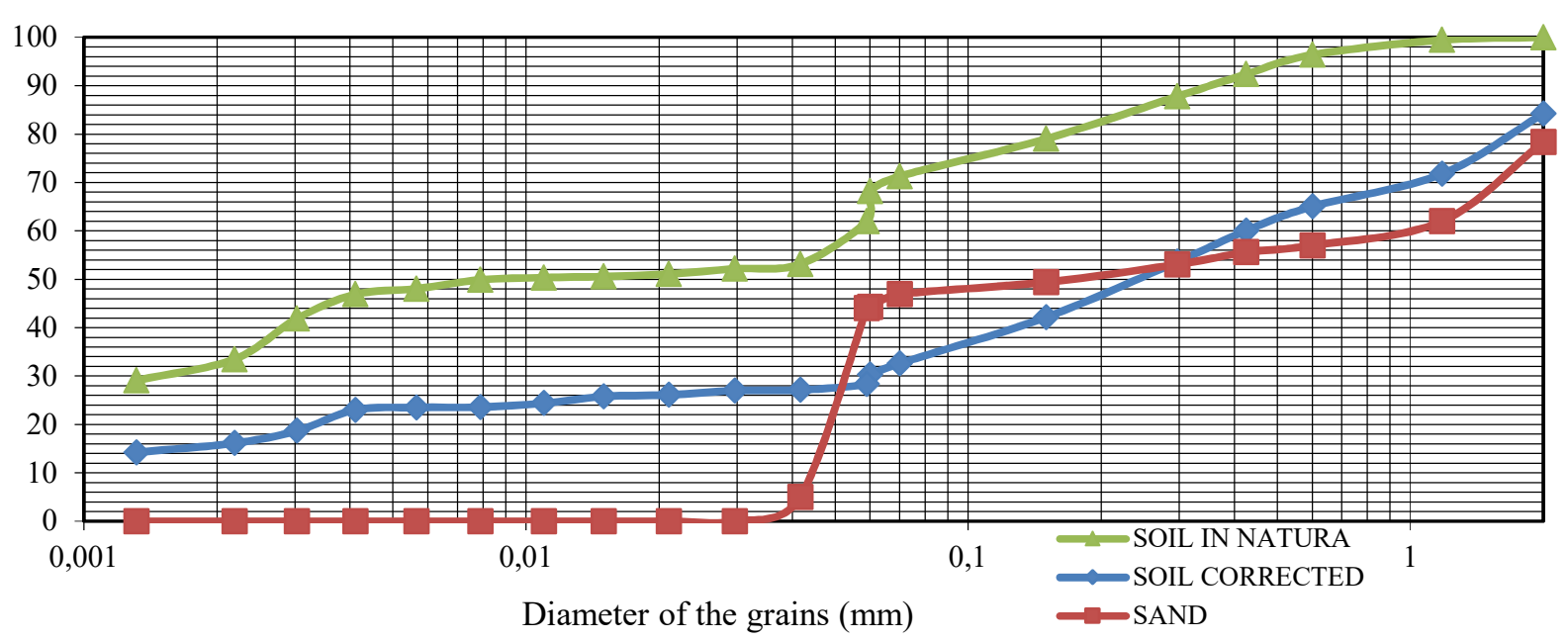

FIGURE 1. Granulometric curve for the soil in natura, soil corrected and sand for correction.

After correction with sand, it is observed that the corrected soil presented a larger granulometry. The presence of sand and the larger particle size is important because in the drying process of adobe, the clay has space to expand and no cracks occur. Another beneficial factor for the presence of sand is for the removal of the adobes from the molds, since the wet clay grabs the walls of the form.

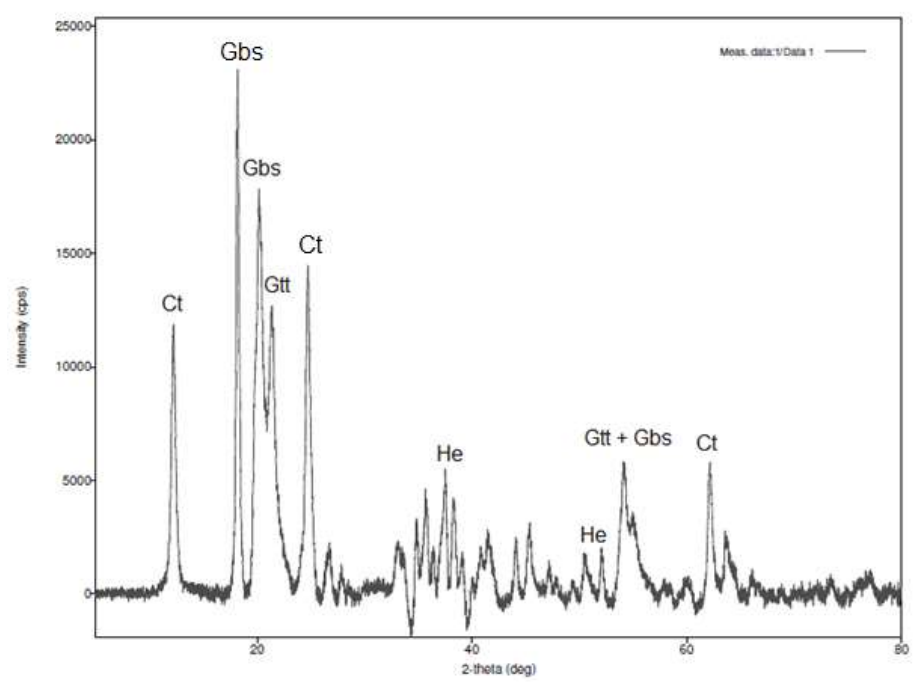

Ct (kaolinite), Gbs (gibsite), Gtt (goethite) and He (hematite).

FIGURE 2. Diffractogram of the sample of soil Red Latosol in natura of the clay fraction

$\mathrm{X}$-ray diffractometry is important for identifying the type of clay present in the soil in order to know its behavior. Inda Junior \& Kampf (2005) analyzed the soil in the same region and found the predominant presence of kaolin in the clay-mineral part of the soil using the X-ray diffraction test.

The benefit of kaolinite - Ct (1-1) is that it has strong bonds and prevents the adsorption of water without significant expansion in contact with water, reducing the cracks in the drying process. Kaolinite is the ideal clay for the manufacture of adobe.

The "synthetic termite saliva" was provided by Blinda Solo and the physico-chemical properties are listed in Table 2.

TABLE 2. Properties of "synthetic termite saliva".

\begin{tabular}{ccc}
\hline Analysis & Property & Unit \\
\hline Appearance & Clear solution & - \\
Density at $25^{\circ} \mathrm{C}$ & Green or brown & $\mathrm{g} \mathrm{cm}^{-3}$ \\
$\mathrm{pH}($ solution a $1 \%)$ & 1.035 & - \\
Solubility in water & 10.5 & - \\
Ionic character & Total & - \\
Radioactivity & Anionic & - \\
Environment & Nonexistent & - \\
\hline
\end{tabular}

Source: Adapted from Blinda Solo Company (2017) 
STS has its physical state as a liquid, facilitating its application. Because it is a nontoxic and nonradioactive product, STS has a more manageable handling and is considered a more sustainable product. STS is a nonpolluting product and its useful life is relatively high.

The STS in contact with the catalyst and the soil forms an insoluble and permanent organic metal composite. Its strong agglutinating action is due to base exchanges, with a larger attraction occurring between the surfaces of the argillaceous particles. The process results in the flocculation and decantation of the clay particles, thus preventing the leaching of the structural composition of the treated soil (Corrêa et al., 2015). The use of STS promotes two significant properties: high particle cohesion and high hydrophobic power.

\section{Composite production}

Following the manufacturer's recommendation for sandy soils, it is necessary to apply aluminum sulphate $\left(\mathrm{Al}_{2}\left(\mathrm{SO}_{4}\right)_{3}\right)$ as a reagent. The use of aluminum sulphate is necessary to accelerate the reaction between the components of the product with the soil; it acts as a catalyst. The $1 \%$ aluminum sulphate solution was made with a ratio of 1: 5000 distilled water. STS was also prepared with distilled water at the proposed treatment concentrations: 1: 1000, 1: 500, 1: 250 and 1: 125 (STS:dry soil) by mass.

The production of samples (Figure 3) was done with the soil corrected with sand, water, and solutions of STS with aluminum sulfate. Before the production of each treatment, 3 soil samples were collected to calculate the soil moisture by the oven method at $103 \pm 2{ }^{\circ} \mathrm{C}$. The amount of water added in the production varied between the liquid limit and plastic limit of the soil, discounting the water used in the solutions of STS and aluminum sulfate. To determine the ideal moisture and consistency, two empirical tests were performed (Figure 3): "Fall of the Ball" (Barbosa \& Ghavami, 2007) and the "Vicat Test" (Ruiz \& Luna, 1983). These were measured by the oven method at $103 \pm 2{ }^{\circ} \mathrm{C}$ in 3 samples by mass of the adobe

For good quality adobes, it must be homogenized, so the production had 3 stages: manual mixing with shovels and hoes, trampling and homogenization in the "maromba".

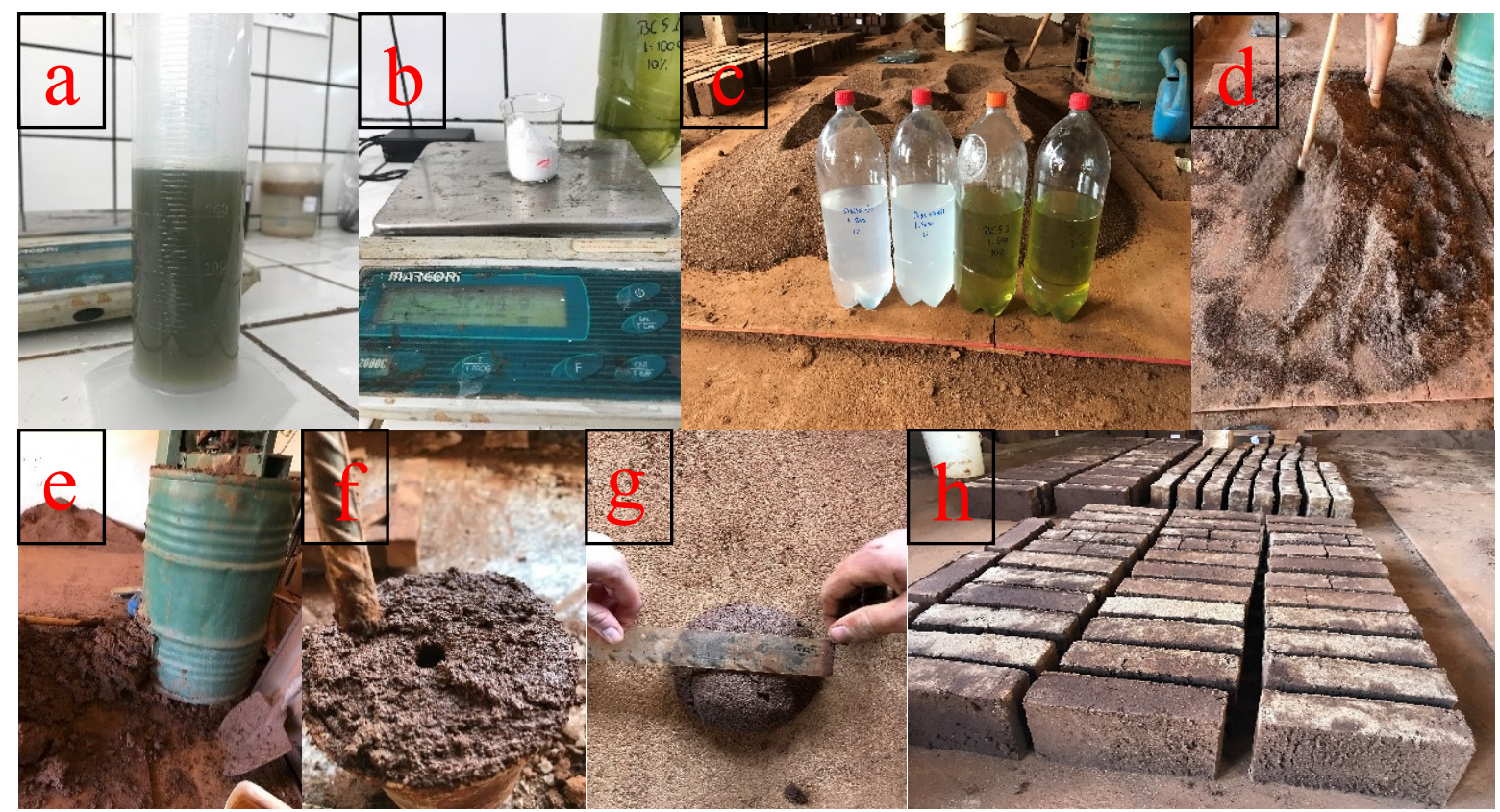

"Synthetic termite saliva" (a), aluminum sulfate (b), solutions of STS and aluminum sulfate for STS2 (c), soil corrected + solution of STS and aluminum sulfate (d), homogenization using the "maromba" (e), "ball drop" test (f) and Vicat test (g) adobes made and turned after 7 days (h).

FIGURE 3. Production steps and humidity test.

\section{Physical tests}

The bulk density test was done with 5 randomly chosen adobes after 35 days of drying. Ten measurements were made per adobe using a scalimeter device of $30 \mathrm{~cm}$ and being weighed on a digital scale in grams.

For the linear shrinkage test, a box proposed by Faria (2002) and adapted was prepared for 6 samples with $60 \times 8.5 \times 3.5 \mathrm{~cm}$, with 2 treatments with 3 replicates each. The boxes were filled with the mass used to produce the adobe, the surface was smoothed to level and each sample was adjusted. After a period of 7 days, the linear retraction of each treatment was measured. The retraction cannot exceed $20 \mathrm{~mm}$ for bricks and soil-cement blocks according to BNH (1985).

The water absorption and mass loss tests were performed according to the modified methodology of Varum et al. (2007). For each treatment, 5 samples of adobes were cut in half after drying. The previously weighed samples were placed in a box of $60 \times 35 \times 10 \mathrm{~cm}$ and filled with water (17 liters) until the samples were submerged. After 6 hours, the samples were weighed again to obtain the amount of water absorbed. The soil material deposited in the boxes was collected and oven dried to calculate the mass loss. 
The capillary test was performed according to the modified methodology of Varum et al. (2007). For each treatment, 5 adobes were used and placed in a plastic container. An amount of water with $1.4 \mathrm{~cm}$ of height was added. After one hour, four measurements of the height of adsorbed (capillarity) water were made: two in width and two in length. The material deposited in the containers was collected and oven dried to calculate the mass loss.

\section{Compressive strength tests}

The NTE (2000) recommends cutting the samples after the drying time. In this work, a change was proposed: cut the samples after they were removed from the mold, 0 days. The adobe with high water content can be sectioned with a nylon line or even with a piece of wire. The interest in cutting wet adobe is due to the greater practicality and to the reduction in electrical energy usage and in dangers associated with using electric tools.

Two compressive strength tests were performed. Both tests followed the NTE (2000) methodology. The first one followed the norm completely, and the second test consisted of cutting the adobe after it was removed from the molds, as shown in Figure 4.

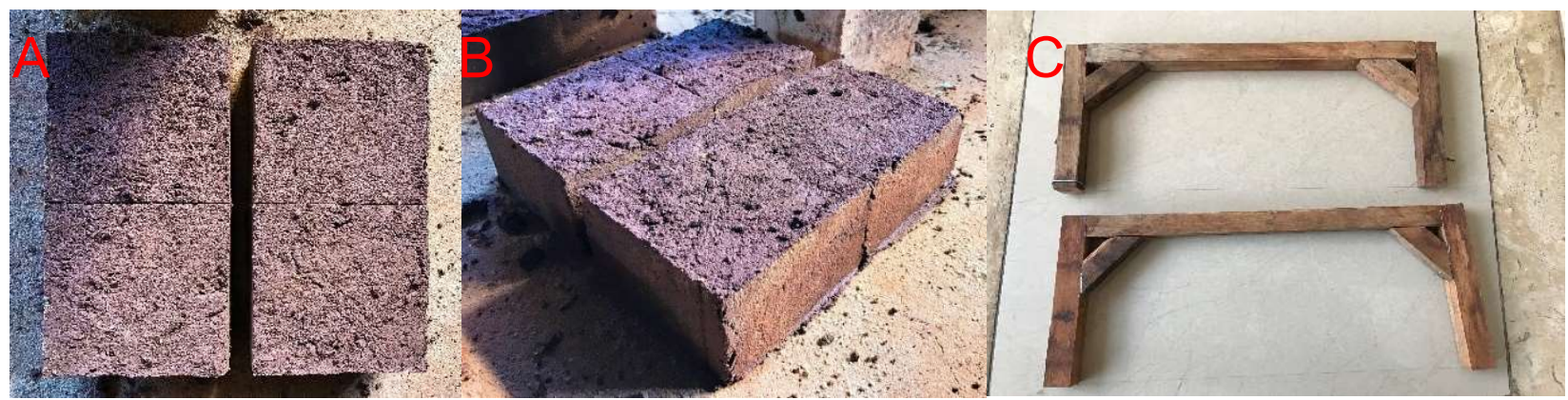

Top view of the adobes cut after the demolding (A), side view of the adobes cut after the demolding and (B) apparatus created to cut the adobes (C). FIGURE 4. Methodology proposed to cut the adobe for the compression test.

\section{Thermal conductivity tests}

The thermal conductivity assay was performed in a chamber developed by MDP (Medium Density Particleboard) of cane bagasse. The chamber has two layers of coatings: styrofoam and a thermal blanket in order to isolate the external medium. The lower part has the heat source (incandescent lamp) connected to a thermostat maintaining the temperature at $47.0{ }^{\circ} \mathrm{C}$.
The system had 4 thermocouples: the lamp temperature controller, the ambient temperature, the temperature before entering the sample and the temperature after exiting the sample. The entire system is connected to an Arduino. To validate the system, the verification of the heat output (Figure 5) was made with an infrared sensor camera, Fluke TI55FT20 / $54 / 7.5$, with an accuracy of $\pm 0.05^{\circ} \mathrm{C}$.
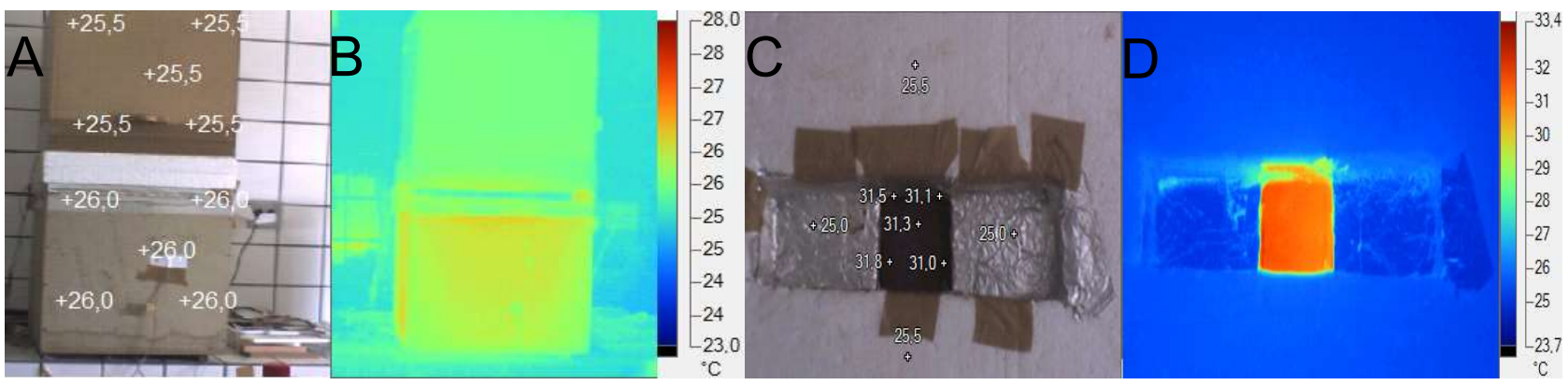

External view of the camera with point temperatures (A). Infrared image of the thermal box and temperature chart (B). Sample location and point temperatures, showing that there is heat insulation (C). Thermographic image of the thermal box and temperature scale (D).

FIGURE 5. External and upper sample view of the thermal box and its thermographic image.

Samples for the thermal assay were taken from the retraction box test after 35 days. The sample sizes are $7 \times 7.5$ length and width with a variable height for each sample, varying between 2.5 and $3 \mathrm{~cm}$ depending on the retraction that each addition had. Sampling time was predetermined in 3.33 hours, referring to 1000 readings of 12 seconds each. Five replicates were made per treatment, and the value of the intermediate sample was used.
For calculating the thermal conductivity, the following equation was used, proposed by Silva (2010):

Where,

$$
K=P . E / \Delta T
$$

$\Delta T$ - temperature difference to stabilization $\left(\mathrm{C}^{\mathrm{o}}\right)$. 
The radiation of the lamp was obtained by a solar radiation meter Instrutherm model MES-100. Five samples were collected, and the mean value calculated was 207.34 $\mathrm{W} \mathrm{m}^{-2}$. The temperature variation $(\Delta \mathrm{T})$ was collected during the sampling of 3.33 hours.

\section{Microstructure}

Microstructural visualization was done using the SMZ 1500 epi-fluorescence (Nikon) stereoscope microscope. The samples used were from the adobe fragments after the compressive strength test.

\section{RESULTS AND DISCUSSION}

With the addition of STS, there was an increase in bulk density (shown in Table 3 ) in relation to the control treatment, however his increase with the STS addition did not demonstrate a significant difference. Corrêa et al. (2014), using concentrations of $0.05 ; 0.067 ; 0.1$ and $0.2 \%$, also found an increase in bulk density, but only at concentrations above $0.1 \%$. It can be affirmed that the use of STS increases the bulk density, but higher concentrations of STS do not proportionally increase the bulk density.

TABLE 3. Mean results for bulk density.

\begin{tabular}{cccccccc}
\hline Treatment & $\begin{array}{c}\text { Length } \\
(\mathrm{cm})\end{array}$ & $\begin{array}{c}\text { Width } \\
(\mathrm{cm})\end{array}$ & $\begin{array}{c}\text { Height } \\
(\mathrm{cm})\end{array}$ & $\begin{array}{c}\text { Volume } \\
\left(\mathrm{cm}^{3}\right)\end{array}$ & $\begin{array}{c}\text { Mass } \\
(\mathrm{g})\end{array}$ & $\begin{array}{c}\text { Density } \\
\left(\mathrm{g} \mathrm{cm}^{-3}\right)\end{array}$ & $\begin{array}{c}\text { Standard deviation } \\
\left(\mathrm{g} \mathrm{cm}^{-3}\right)\end{array}$ \\
\hline Control & 29.26 & 14.72 & 7.69 & 3311.33 & 5.362 & $1.619 \mathrm{a}$ & 0.023 \\
STS1 & 29.36 & 14.67 & 7.98 & 3438.55 & 6.040 & $1.757 \mathrm{~b}$ & 0.030 \\
STS2 & 29.37 & 14.73 & 8.01 & 3466.78 & 6.092 & $1.757 \mathrm{~b}$ & 0.029 \\
STS4 & 29.20 & 14.55 & 7.83 & 3326.55 & 5.817 & $1.749 \mathrm{~b}$ & 0.017 \\
STS8 & 29.17 & 14.47 & 7.94 & 3350.02 & 6.023 & $1.798 \mathrm{~b}$ & 0.021 \\
General average (\%) & & & & & 1.74 & & 1.57 \\
Variation coefficient (\%) & & & & & & \\
\hline
\end{tabular}

The mean, followed by the same letter in the same row are statistically the same by Tukey's test at $5 \%$ significance.

With the increase in the STS concentration, a decrease in the water absorbed and a smaller loss of mass occurred. In Figure 6, the decrease in mass and the structuring of the samples with an increase in the amount of STS is visually observed. The values for mass absorption and loss are shown in Table 4.

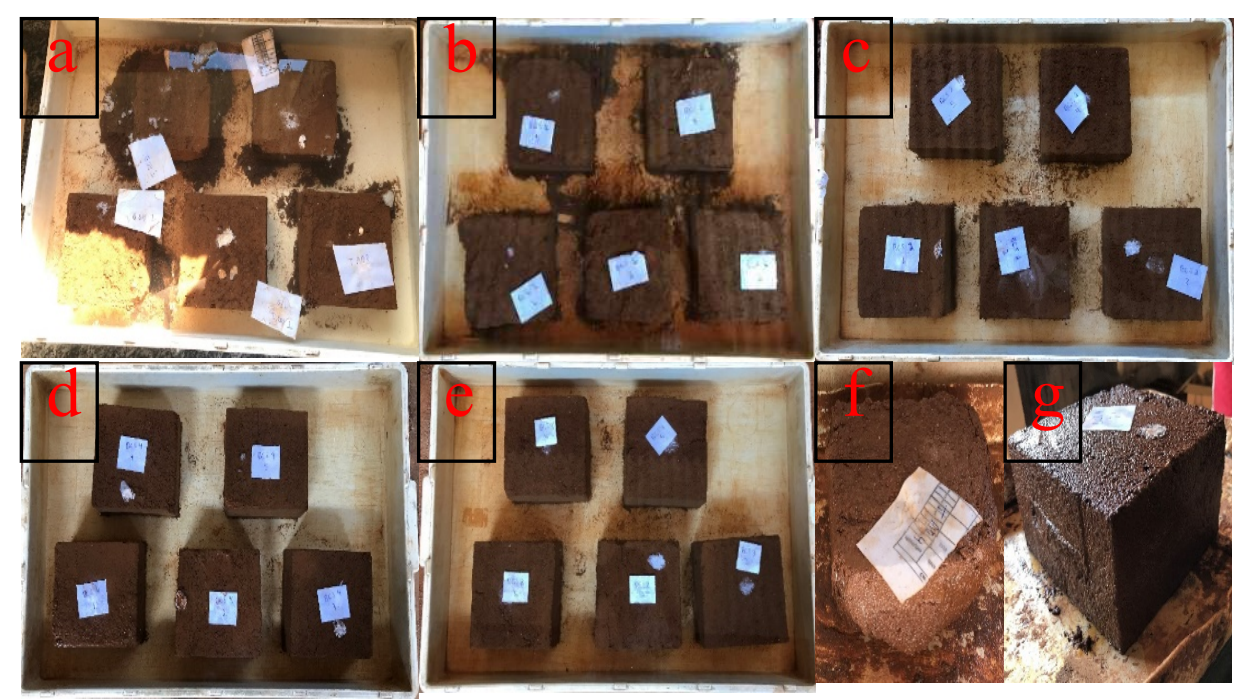

Control (a), STS1 (b), STS2 (c), STS4 (d), STS8 (e), sample C after assay (f) and STS4 sample after assay.

FIGURE 6. Adobes after 6 hours submerged in water.

Corrêa et al. (2015), using STS at a ratio of 1: 1500 (0.067\% by mass), stabilized an adobe soil that had previously disintegrated in contact with water by decreasing the water absorption by $15 \%$. Faria et al. (2016), using the STS at $0.1 \%$ (1: 1000 ) in soil-cement brick, found a $13.11 \%$ improvement in water absorption. 
TABLE 4. Average results for water absorption and mass loss.

\begin{tabular}{|c|c|c|c|c|c|c|c|}
\hline Treatment & $\begin{array}{c}\text { Water absorption } \\
(\%)\end{array}$ & $\begin{array}{l}\text { Initial mass } \\
(\mathrm{kg})\end{array}$ & $\begin{array}{c}\text { Final Mass } \\
(\mathrm{kg})\end{array}$ & $\begin{array}{l}\text { General } \\
\text { average }\end{array}$ & & $\begin{array}{c}\text { Dry mass loss } \\
(\mathrm{kg})\end{array}$ & $\begin{array}{c}\text { Dry mass loss } \\
(\%)\end{array}$ \\
\hline Control & $12.03 \mathrm{a}$ & 13.120 & 14.384 & 7.642 & $*$ & 0.779 & 0.059 \\
\hline STS1 & $8.85 b$ & 14.752 & 16.184 & 0.263 & & 0.204 & 0.014 \\
\hline STS2 & $7.77 b c$ & 14.700 & 15.938 & 0.123 & & 0.047 & 0.003 \\
\hline STS4 & $6.31 \mathrm{c}$ & 14.202 & 15.156 & 1.086 & & 0.019 & 0.001 \\
\hline STS8 & $6.98 \mathrm{c}$ & 15.026 & 16.154 & 0.606 & & 0.015 & 0.001 \\
\hline General average $(\%)$ & 8.23 & & & & & & \\
\hline Variation coefficient $(\%)$ & 9.2 & & & & & & \\
\hline
\end{tabular}

* One of the 5 samples was significantly damaged.

The mean, followed by the same letter in the same row are statistically the same by Tukey's test at $5 \%$ significance.

Albuquerque et al. (2008), when comparing a Neosol and a soil with a large volume of termite mounds in the production of soil cement brick, observed that termite soil presented a lower water absorption. In Figure 7, it is possible to see the graph of the trend between STS and water absorption and its respective loss of mass.

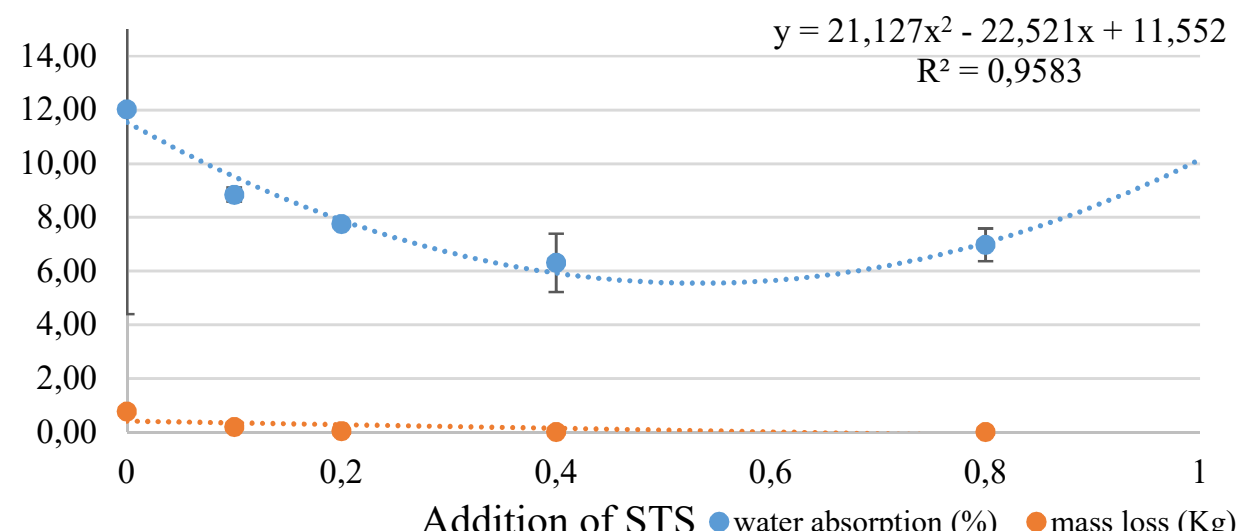

FIGURE 7. Graph of water absorption and mass loss.

Note that by the polynomial equation (2) the value of $\mathrm{R}^{2}$ is considerable.

$\mathrm{y}=0.5241 \mathrm{x}^{2}-4.4096 \mathrm{x}+15.851$ (2) corresponding to:

$\mathrm{y}$ - water absorption, $\%$, and

$\mathrm{x}-\mathrm{STS}$ addition, $\%$.

The values for capillarity are presented in Table 5. It is observed that when the increase of the addition of STS occurs there is a decrease of water height and a loss of mass. At the significant level of $5 \%$, the results differ, with the best result being the use of $0.8 \%$.

TABLE 5. Mean results for capillarity and mass loss.

\begin{tabular}{|c|c|c|c|c|c|c|}
\hline Treatments & $\begin{array}{l}\text { Average capillarity height } \\
(\mathrm{cm})\end{array}$ & $\begin{array}{l}\text { General average } \\
(\mathrm{cm})\end{array}$ & $\begin{array}{c}\text { Initial mass } \\
(\mathrm{kg})\end{array}$ & $\begin{array}{c}\text { Final mass } \\
(\mathrm{kg})\end{array}$ & Mass loss (kg) & $\begin{array}{c}\text { Mass loss } \\
(\%) \\
\end{array}$ \\
\hline Control & $2.06 \mathrm{a}$ & 0.361 & 27.152 & 30.302 & 0.068 & 0.0025 \\
\hline STS1 & $1.79 \mathrm{ab}$ & 0.276 & 30.357 & 31.641 & 0.124 & 0.0041 \\
\hline STS2 & $1.72 \mathrm{ab}$ & 0.110 & 29.642 & 30.346 & 0.029 & 0.0010 \\
\hline STS4 & $1.61 \mathrm{ab}$ & 0.429 & 28.840 & 29.450 & 0.017 & 0.0006 \\
\hline STS8 & $1.32 \mathrm{~b}$ & 0.334 & 29.946 & 30.528 & 0.019 & 0.0006 \\
\hline General average $(\%)$ & 1.70 & & & & & \\
\hline Variation coefficient $(\%)$ & 18.88 & & & & & \\
\hline
\end{tabular}

The mean, followed by the same letter in the same row are statistically the same by Tukey's test at $5 \%$ significance. 
The capillarity observed by Corrêa et al. (2014a) presented similar results, with the decrease of rising water occurring according to the increase of STS addition. Albuquerque et al. (2008), comparing a Neosol and a soil with a large volume of termite mounds in the manufacture of soil cement-brick, observed that the termite soil presented a lower water absorption.
The linear shrinkage presented a significant difference according to the addition of STS (Table 6). The results are in accordance with the recommendations of the BNH (1985) and CEPED (1984), presenting retraction values lower than $20 \mathrm{~mm}$. Corrêa et al. (2015), using a concentration of $0.067 \%$, also found a smaller retraction. Figure 8 shows the retraction boxes after 7 days.

TABLE 6. Mean linear shrinkage of different treatments.

\begin{tabular}{|c|c|c|c|c|c|}
\hline \multirow{2}{*}{ Average results } & \multicolumn{5}{|c|}{ Treatments } \\
\hline & Control & STS1 & STS2 & STS4 & STS8 \\
\hline Linear shrinkage $(\mathrm{cm})$ & $2.71 \mathrm{a}$ & $1.91 \mathrm{~b}$ & $1.93 b$ & $1.91 \mathrm{~b}$ & $1.95 b$ \\
\hline Linear shrinkage (\%) & 0.05 & 0.03 & 0.03 & 0.03 & 0.03 \\
\hline Standard deviation & 0.03 & 0.10 & 0.02 & 0.13 & 0.04 \\
\hline General average (\%) & \multicolumn{5}{|c|}{2.08} \\
\hline Variation coefficient $(\%)$ & \multicolumn{5}{|c|}{4.64} \\
\hline
\end{tabular}

The mean, followed by the same letter in the same row are statistically the same by Tukey's test at $5 \%$ significance.

Corrêa et al. (2014a), using 1: 2000 STS; 1: 1500; 1: 1000 and 1: 500, observed the same similarity; the use of STS decreases retraction but has no significant difference with an increasing dosage.

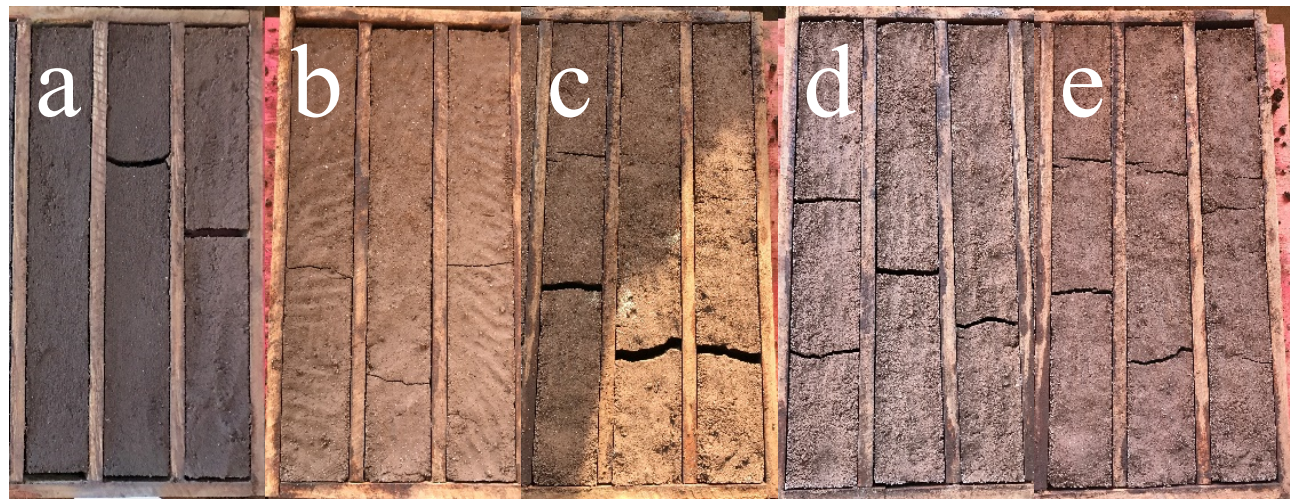

Control (a), STS1 (b), STS2 (c), STS4 (d) e STS8 (e).

FIGURE 8. Linear shrinkage test.

Figure 9 presents the results for the thermal conductivity. The results did not show significant differences at the $5 \%$ level, and the use of STS does not alter the thermal properties of the adobe.

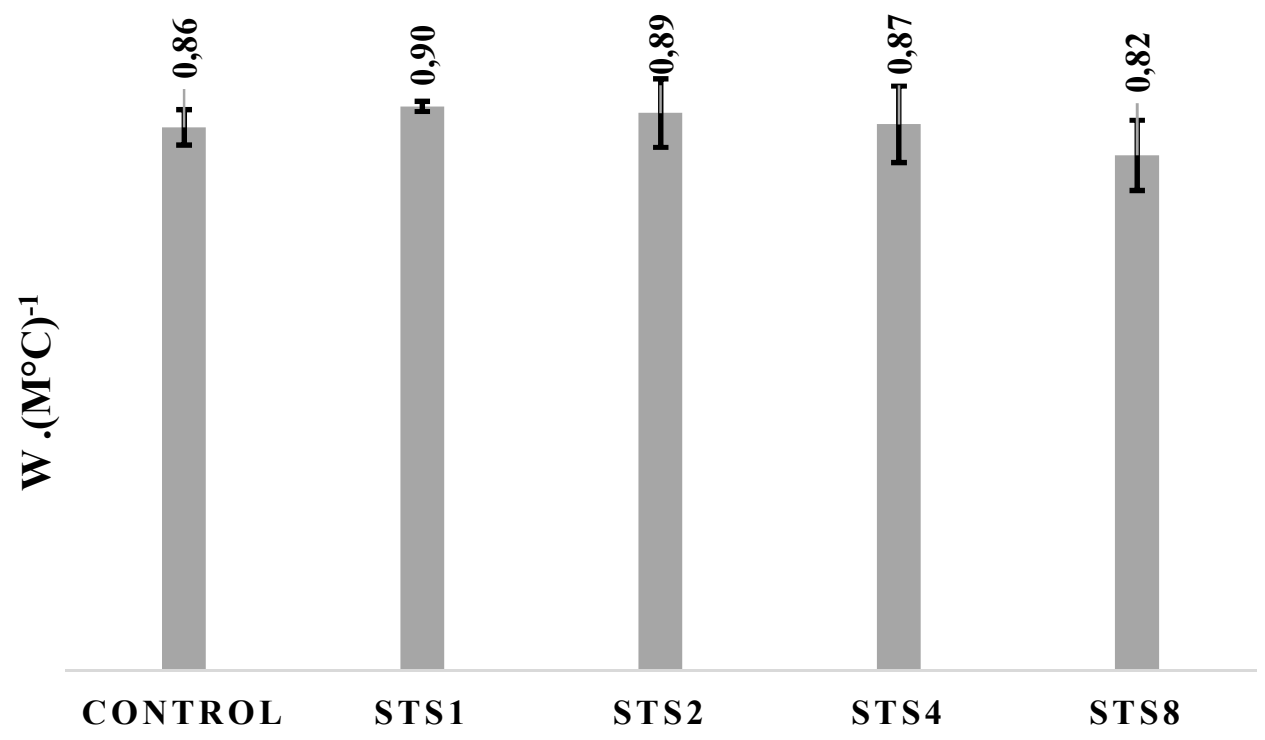

FIGURE 9. Adobe thermal conductivity. 
It is noteworthy that the use of STS in the adobe is very restricted, and no thermal conductivity analysis was found with the use of STS. Mosquera et al. (2014), using two samples of adobe, one drying in an oven and another one with $1.67 \%$ of humidity, found values of 0.80 and 0.90 $\mathrm{W} .\left(\mathrm{m}^{\circ} \mathrm{C}\right)^{-1}$. The value of the control is $0.86 \mathrm{~W} .\left(\mathrm{m}^{\circ} \mathrm{C}\right)^{-1}$. Other authors have found values between 0.5 and
0.7 W. $\left(\mathrm{m}^{\circ} \mathrm{C}\right)^{-1}$ (Holman, 1969; Karlelar, 1990 cited by Piñon et al., 2007).

The compressive strength was significant at the $5 \%$ level, but the addition of STS interfered negatively (Table 7). The standard NTE E.080 (2000) establishes acceptable values of compressive strength $\geq 0.7 \mathrm{MPa}$, therefore all samples were acceptable.

TABLE 7. Analysis of compressive strength in MPa.

\begin{tabular}{|c|c|c|c|c|c|}
\hline Treatment & NTE E0.80 & $\begin{array}{l}\text { Standard } \\
\text { deviation }\end{array}$ & NTE E0.80 modified & $\begin{array}{l}\text { Standard } \\
\text { deviation }\end{array}$ & Average per treatment \\
\hline $\mathrm{C}$ & 1.43 & 0.12 & 1.35 & 0.08 & $1.39 \mathrm{a}$ \\
\hline STS1 & 1.28 & 0.12 & 1.14 & 0.11 & $1.21 \mathrm{~b}$ \\
\hline STS2 & 1.30 & 0.06 & 1.38 & 0.11 & $1.34 \mathrm{ab}$ \\
\hline STS4 & 1.18 & 0.05 & 1.23 & 0.10 & $1.21 \mathrm{~b}$ \\
\hline STS8 & 1.41 & 0.10 & 1.35 & 0.13 & $1.38 \mathrm{ab}$ \\
\hline
\end{tabular}

The mean, followed by the same letter in the same row are statistically the same by Tukey's test at $5 \%$ significance.

The control treatment presented the greatest resistance to compression. Additions of $0.1 \%$ and $0.4 \%$ had the lowest values. The additions of $0.2 \%$ and $0.8 \%$ presented intermediate and statistically equal values to the other treatments. This variation in the compressive strength not being proportional to the addition of STS in the adobe can be due to two factors. First, the high cohesive power makes the adobe material with higher density increase its resistance to compression, as presented in Table 3. The second factor is that with the greater addition of STS, the water loss will be faster; therefore, cracks may occur in its drying process, reducing its resistance to compression.
Faria et al. (2016), using STS with cement in soilcement, obtained a significant increase in the resistance to compression; whereas Corrêa et al. (2014b), using only STS in several proportions, obtained small differences in the resistance to compression. This result shows that to improve the compressive strength of the adobes, it is necessary use STS with other stabilizers.

\section{Microstructure}

The microstructural interaction of the adobe samples are observed in Figure 10. It is possible to observe that the control treatment presents a greater quantity of pores and therefore, the largest area when compared to treatment STS4 with $0.4 \%$ of addition.

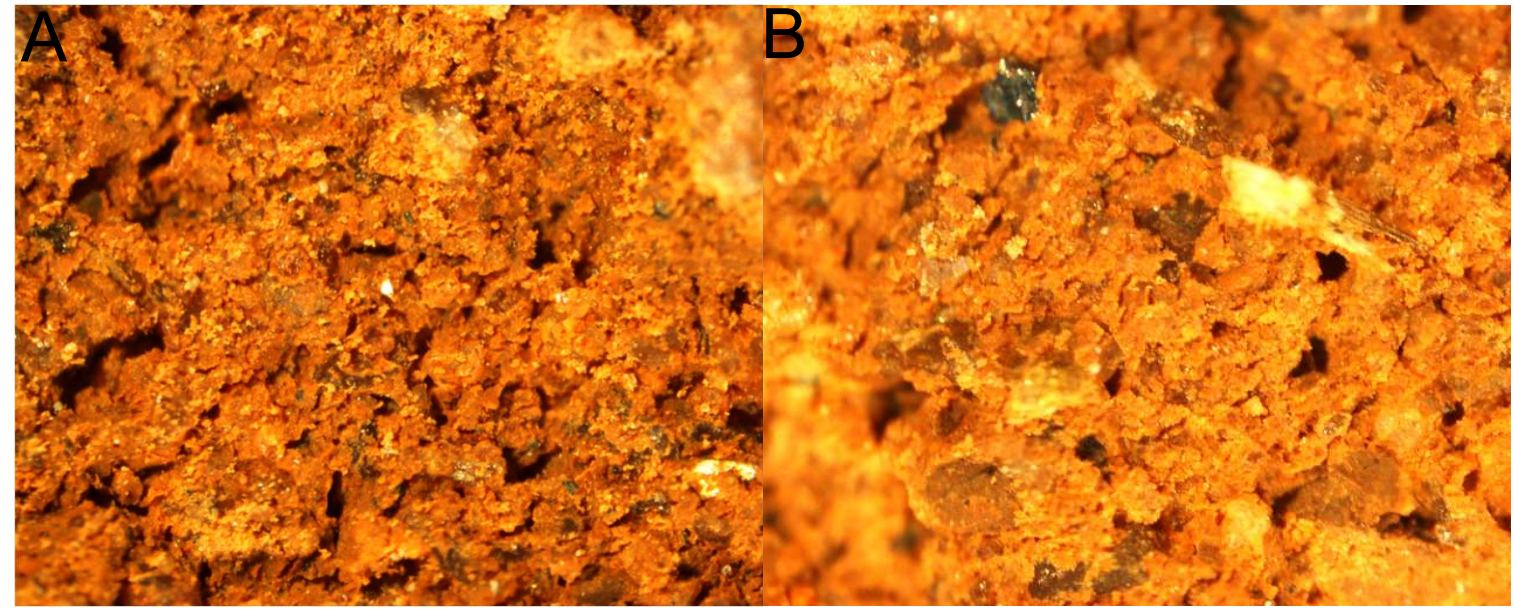

Treatment $\mathrm{C}$ with 30X increase (A) and Treatment STS4 with 30X increase (B).

FIGURE 10. Stereoscopic microscopy images of the treatments.

The effect of an STS addition provides a greater interaction of the soil with the clay-mineral particle, increasing the cohesion of the particles. With the decrease in the number of pores, the bulk density increases, as presented in Table 3. This result is also confirmed by the presence of micro cracks in Figure 10 and macro cracks in Figure 8 . The cracks are caused by the hydrophobic power of the STS, which expels the water quickly from the adobes during the drying period.

Corrêa et al. (2015) also observed the strong adherence of the adobe using STS and sugarcane bagasse particles in one and bamboo fibers in another, using the stereoscope microscope. 


\section{CONCLUSIONS}

The use of "synthetic termite saliva" interferes with the physical and mechanical properties of adobe. The level of the improvements in the physical properties of adobe related to water contact are significantly higher, solving the problem of this issue. The best addition of STS, considering its high commercial value and the improvement in properties, is $0.2 \%$ by mass of the adobe. The use of STS did not influence the thermal conductivity in adobes. The use of STS negatively interfered with compressive strength, but the interference did not preclude its use according to the NTE E.080.

It is recommended in future research to use STS along with another stabilizer. It is possible that the use of natural or synthetic fibers with STS would increase its compressive strength, prevent cracking and maintain and/or improve the favorable results of its properties in contact with water.

\section{ACKNOWLEDGMENTS}

The authors would like to thank the Brazilian agencies Capes, CNPq and FAPEMIG for their support of this research.

\section{REFERENCES}

Aguilar R, Nakamatsu J, Ramírez E, Elgegren M, Kim S, Pando MA, San-Martin LO (2016) The potential use of chitosan as a biopolymer additive for enhanced mechanical properties and water resistance of earthen construction. Construction and Building Materials 114:625-637. DOI: https://doi.org/10.1016/j.conbuildmat.2016.03.218

Albuquerque LQC, Biscaro GQ, Negro SRL, Oliveira AC, Carvalho LA, Leal ST (2008) Resistência à compressão de tijolos de solo-cimento fabricados com o montículo do cupim Cornitermes cumulans (Kollar, 1832). Ciência e Agrotecnologia 32(2):553-560. DOI:

https://doi.org/10.1590/S1413-70542008000200032

ABNT - Associação Brasileira de Normas Técnicas (1981) NBR-7180. Solo - Determinação do limite de plasticidade. Método de Ensaio. ABNT, 3 p.

ABNT - Associação Brasileira de Normas Técnicas (1982) NBR-7183. Determinação do Limite e Relação de Contração dos Solo. Método de Ensaio. ABNT, 3 p.

ABNT - Associação Brasileira de Normas Técnicas (1984) NBR-7181. Análise Granulométrica. Método de Ensaio. ABNT, $13 \mathrm{p}$.

ABNT - Associação Brasileira de Normas Técnicas (1986) NBR-9776. Agregados - Determinação da massa específica de agregados miúdos por meio do frasco Chapman. Método de Ensaio. ABNT, 3 p.

ABNT - Associação Brasileira de Normas Técnicas (2004) NBR-6459. Determinação do Limite de Liquidez. Método de Ensaio. ABNT, 6 p.

BNH - Banco Nacional da Habitação (1985)

Uniformização das técnicas de aplicação do solo-cimento na construção habitacional. DEPEA/BNH, 14p.
Balkis AP (2017) The effects of waste marble dust and polypropylene fiber contents on mechanical properties of gypsum stabilized earthen. Construction and Building Materials 134:556-562. DOI:

https://doi.org/10.1016/j.conbuildmat.2016.12.172

Barbosa NP, Ghavami K (2007) Terra crua para edificações. materiais de construção civil e princípios de ciência e engenharia de materiais. Ibracon, 2 ed. p 1505-1557.

CEPED - Centro de Pesquisas e Desenvolvimento. THABA (1984) Manual de construção com solo-cimento. CEPED, 3 ed. 147 p.

Corrêa AAR, Mendes LM, Barbosa NP, Protásio TP, Campos NA, Tonoli GHD (2015) Incorporation of bamboo particles and "synthetic termite saliva" in adobes. Construction and Building Materials 98:250-256. DOI: https://doi.org/10.1016/j.conbuildmat.2015.06.009

Corrêa AAR, Guimarães BMR, Scatolino MV, Duarte MG, Lopes TA, Mendes LM (2014a) Evaluation of physical properties of adobe chemically stabilized with synthetic termite saliva. Key Engineering Materials 600:144-149. DOI:

10.4028/www.scientific.net/KEM.600.144

Corrêa AAR, Bufalino L, Protásio TP, Ribeiro MX, Wisky D, Mendes LM (2014b) Evaluation of Mechanical Properties of Adobe Chemically Stabilized with" Synthetic Termite Saliva". Key Engineering Materials 600:150-155. DOI: 10.4028/www.scientific.net/KEM.600.150

Dove CA, Bradley FF, Patwardhan SV (2016) Seaweed biopolymers as additives for unfired clay bricks. Materials and Structures 49(11):4463-4482. DOI: https://doi.org/10.1617/s11527-016-08010

Eires R, Camôes A, Jalali S (2017) Enhancing water resistance of earthen buildings with quicklime and oil. Journal of Cleaner Production 142:3281-3292. DOI: https://doi.org/10.1016/j.jclepro.2016.10.141

EMBRAPA - Empresa Brasileira de Pesquisa Agropecuária (2013) Sistema brasileiro de classificação de solos. Brasília: Embrapa Solos, 342p.

Faria OB (2002) Utilização de macrófitas aquáticas na produção de adobe: um estudo no reservatório de Salto Grande (Americana-SP). Tese, São Paulo Universidade de São Paulo, Escola de Engenharia de São Carlos.

Faria OB, Battistelle RA, Neves C (2016) Influence of the addition of" synthetic termite saliva" in the compressive strength and water absorption of compacted soilcement. Ambiente Construído 16(3):127-136. DOI: http://dx.doi.org/10.1590/s1678-86212016000300096

Fratini F, Pecchioni E, Rovero L, Tonietti U (2011) The earth ir the architecture of the historical centre of Lamezia Terme (Italy): characterization for restoration. Applied Clay Science 53:509-516. DOI: https://doi.org/10.1016/j.clay.2010.11.007

Galán-Marín C, Rivera-Gómez C, Petric J (2010) Claybased composite stabilized with natural polymer and fibre.

Construction and Building Materials 24(8):1462-1468. DOI: https://doi.org/10.1016/j.conbuildmat.2010.01.008 
Gandia RM, Campos AT, Corrêa AAR, Gomes FC (2018) Energy costs comparison of masonry made from different materials. Theoretical and Applied Engineering 2(1):1-8. DOI: https://doi.org/10.31422/taae.v2i1.2

Hamard E, Cazacliu B, Razakamanantsoa A, Morel JC (2016) Cob, a vernacular earth construction process in the context of modern sustainable building. Building and Environment 106:103-119. DOI:

https://doi.org/10.1016/j.buildenv.2016.06.009

Inda Junior AV, Kampf N (2005) Variabilidade de goethita e hematita via dissolução redutiva em solos de região tropical e subtropical. Revista brasileira de ciência do solo 29(6):851-866.

DOI: https://doi.org/10.1590/S0100-06832005000600003

Illampas R, Ioannou I, Charmpis DC (2014) Adobe bricks under compression: experimental investigation and derivation of stress-strain equation. Construction and Building Materials 53:83-90. DOI:

https://doi.org/10.1016/j.conbuildmat.2013.11.103

Laborel-Préneron A, Aubert JE, Magniont C, Tribout C, Bertron A (2016) Plant aggregates and fibers in earth construction materials: A review. Construction and Building Materials 111:719-734. DOI: https://doi.org/10.1016/j.conbuildmat.2016.02.119

Millogo Y, Aubert JE, Séré AD, Fabbri A, Morel JC (2016) Earth blocks stabilized by cow-dung. Materials and Structures 49(11):4583-4594. DOI: https://doi.org $10.1617 /$ s1 1527-016-0808-6

Millogo Y, Morel JC, Aubert JE, Ghavami K (2014) Experimental analysis of pressed adobe blocks reinforced with Hibiscus cannabinus fibres. Construction and Building Materials 52:71-78. DOI: https://doi.org/10.1617/s11527-016-0808-6

Mosquera P, Canãs J, Cid-Falceto, Marcos F (2014) Determination of the Thermal Conductivity in Adobe With Several Models. Journal of Heat Transfer 1363(3):031303. DOI: https://doi.org/10.1115/1.4025560

Nakamatsu J, Kim S, Ayarza J, Ramírez E, Elgegren M, Aguilar R (2017) Eco-friendly modification of earthen construction with carrageenan: Water durability and mechanical assessment. Construction and Building Materials 139:193-202. DOI: https://doi.org/10.1016/j.conbuildmat.2017.02.062
NTE - Norma Técnica de Edificación. NTE E.080 (2000) reglamento Nacional construcciones. Lima, 17p.

Piattoni Q, Quagliarini E, Lenci S (2011) Experimental analysis and modelling of the mechanical behaviour of earthen bricks. Construction and Building

Materials 25:2067-2075. DOI:

https://doi.org/10.1016/j.conbuildmat.2010.11.039

Piñon JP, Vega-Durán JT, Manzano-Ramirez A, Pérez-

Robles JF, Balmori-Ramirez H, Hernández-Landaverde MA (2007) Enhancement of mechanical and hydrophobic properties of Adobes for Building Industry by the addition of polymeric agents. Building and Environment 42:877883. DOI: https://doi.org/10.1016/j.buildenv.2005.10.009

Ruiz LEH, Luna JAM (1983) Cartilha de pruebas de campo. Conescal, 72p.

Silva AR (2010) Estudo térmico e de materiais de um bloco para construção de casas populares, confeccionado a partir de um compósito a base de gesso, EPS e raspa de pneu. Dissertation, Natal Universidade Federal do Rio Grande do Norte.

Shukla A, Tiwari GN, Sodha MS (2009) Embodied energy analysis of adobe house. Renewable Energy 34(3):755761. DOI: https://doi.org/10.1016/j.renene.2008.04.002

Stazi F, Nacci A, Tittarelli F, Pasqualini E, Munafò P (2016) An experimental study on earth plasters for earthen building protection: The effects of different admixtures and surface treatments. Journal of Cultural Heritage 17:2741. DOI: https://doi.org/10.1016/j.culher.2015.07.009

Varum H, Costa A, Silveira D, Carvalho G, Silva L (2007) Caracterização dos solos e adobes usados na construção los Camabatelas, Angola. Lisboa, Argumentum p94-96.

Vilane BRT (2010) Assessment of stabilization of adobes by confined compression tests. Biosystems Engineering 106:551-558. DOI:

https://doi.org/10.1016/j.biosystemseng.2010.06.008 